\section{Resistance to Lettuce Aphid (Nasonovia ribisnigri) Biotype 0 in Wild Lettuce Accessions PI 491093 and PI 274378}

\author{
James D. McCreight ${ }^{1}$ and Yong-Biao Liu \\ U.S. Department of Agriculture, Agricultural Research Service, U.S. \\ Agricultural Research Station, 1636 E. Alisal Street, Salinas, CA 93905 \\ Additional index words. Lactuca sativa, Lactuca serriola, Lactuca virosa, red aphid, \\ interspecific
}

\begin{abstract}
The lettuce aphid, Nasonovia ribisnigri Mosley (Hemiptera: Aphididae), is a major insect pest of lettuce, Lactuca sativa $\mathrm{L}$, in many commercial lettuce production areas around the world. Resistance to lettuce aphid biotype $0(\mathrm{Nr}: 0)$ was first reported in Lactuca virosa L. accession IVT 280 and characterized as complete, i.e., virtually no aphids survived, and genetically dominant to partial resistance in $L$. virosa accession IVT 273. Complete and partial resistances to $\mathrm{Nr}: 0$ were conditioned by two alleles, $\mathrm{Nr}$ (complete resistance) and $n r$ (partial resistance), but the genetic relationship to susceptibility was not reported. We previously reported two new potential sources of unique genes for resistance to Nr:0 in Lactuca serriola L. accession PI 491093 and $L$. virosa PI 274378. We report on the genetic and phenotypic nature of resistance to $\mathrm{Nr}: 0$ in these two wild lettuce accessions. Resistance to $\mathrm{Nr}: 0$ in PI 274378 is complete and allelic to complete resistance in IVT 280. Resistance to $\mathrm{Nr}: 0$ in PI 491093 was partial, recessive to complete resistance in 'Barcelona' that was derived from IVT 280 , but dominant to susceptibility in 'Salinas'. We propose the revised gene symbols for resistance to $\mathrm{Nr}: 0$ : $N r: 0^{C}$ for complete resistance and $N r: 0^{P}$ for partial resistance, which was originally designated as $n r$ but may now be regarded as the symbol for susceptibility to all strains of lettuce aphid. The dominance relationships among these three alleles are $\mathrm{Nr}: 0^{C}$ (in IVT 280, 'Barcelona') $>N r: 0^{P}$ (in PI 491093) $>n r$ (in susceptible genotypes). Expression of partial resistance in PI 491093 was variable in controlled infestation tests, but in a naturally infested field test provided a potentially useful level of resistance to $\mathrm{Nr}: 0$. Partial resistance, where complete resistance has not been widely deployed, may either alone or as a component of integrated pest management delay or prevent emergence of genotypes that overcome complete resistance controlled by $\mathrm{Nr}: 0^{C}$.
\end{abstract}

Lettuce (Lactuca sativa L.) is a major leafy vegetable that is grown and harvested year-round in the United States (Davis et al., 1997). California and Arizona produce $68 \%$ and $22 \%$, respectively, of the lettuce grown in the United States (Mou, 2009) with the balance produced in $17+$ other states (USDA, 2011a). Head and leaf lettuce crops were harvested from 56,660 ha in Monterey County, CA, and valued at $\$ 1.24$ billion in 2010 (Lauritzen, 2011). Fresh lettuce leaves are commonly consumed in salads or sandwiches in the United States, Europe, and Australia, but in some countries, elongated stems are eaten; raw in Egypt; and cooked in China (Ryder, 2002).

\footnotetext{
Received for publication 21 Sept. 2011. Accepted for publication 13 Dec. 2011.

Funded in part by a grant from the California Leafy Greens Research Program.

We thank Patti Fashing and Jeff Wasson for assistance in the field tests.

USDA is an equal opportunity provider and employer. Mention of trade names or commercial products in this publication is solely for the purpose of providing specific information and does not imply recommendation or endorsement by the U.S. Department of Agriculture.

${ }^{1}$ To whom reprint requests should be addressed; e-mail jim.mccreight@ars.usda.gov.
}

Lettuce aphid, Nasonovia ribisnigri Mosley (Hemiptera: Aphididae), is an economically important pest of lettuce in Europe (Arend et al., 1999), Canada (Forbes and MacKenzie, 1982), the United States (Chaney, 1999; Palumbo, 2000), New Zealand (Stufkens and Teulon, 2003), Tasmania (Stufkens et al., 2002, 2004), and Australia (Anonymous, 2004). Lettuce aphid may colonize lettuce at any time from the seedling stage of growth onward. High densities of lettuce aphid can Lettuce aphid is also listed as a vector of Cucumber mosaic virus and Lettuce mosaic virus (Blua, 1997), although no incidents of virus transmission have been reported from any lettuce production areas. Lettuce aphid not only reduces marketability of infested lettuce in domestic markets but poses as a phytosanitary barrier for lettuce exports to some overseas markets such as Japan and Taiwan where lettuce aphid is quarantined.

Lettuce aphid is difficult to manage. Its propensity for colonizing the young (core) leaves makes it virtually impossible to control with contact insecticides during head maturation (Liu, 2004). In addition, it can develop resistance to insecticides (Barber et al., 1999; Stufkens and Wallace, 2004). Postharvest control of lettuce aphid on exported lettuce is also deform lettuce heads and change leaf color. challenging. Methyl bromide fumigation causes injuries to lettuce and there are no safe alternative fumigants. Although ultralow oxygen treatment was reported to be safe and effective to control lettuce aphid on harvested head lettuce, the treatment was not effective against leafminer, Liriomyza langei Frick, which is also quarantined in Japan and often intercepted on exported lettuce (Liu, 2005). Genetically based host plant resistance is an economical and environmentally desirable means to control lettuce aphid infestation of lettuce (Painter, 1980).

Two biotypes of lettuce aphid have been known in Europe since 2007 and were designated by The Netherlands Inspection Service for Horticulture (Naktuinbow) as $\mathrm{Nr}: 0$ and Nr: 1 (Thabuis et al., 2011). Biotype Nr:0 is known worldwide, and biotype $\mathrm{Nr}: 1$ is, thus far, known only in Europe. Complete and partial types of resistance to $\mathrm{Nr}: 0$ were described in Lactuca virosa L., a wild, distant relative of cultivated lettuce (Eenink and Dieleman, 1983). Complete resistance to $\mathrm{Nr}: 0$ was the result of a single gene $(\mathrm{Nr})$ that was partially dominant in segregating $\left(\mathrm{F}_{2}\right)$ families from resistant $L$. virosa $\times$ susceptible L. virosa crosses but completely dominant after introgression to cultivated lettuce, $L$. sativa (Eenink and Dieleman, 1983; Eenink et al., 1982b). Partial resistance to $\mathrm{Nr}: 0$ in $L$. virosa was the result of a recessive allele, $n r$, at the same locus (Eenink and Dieleman, 1983). Complete resistance to $\mathrm{Nr}: 0$ in L. virosa accession IVT 280 was transferred to cultivated lettuce (Arend et al., 1999) and is highly effective against California strains of $\mathrm{Nr}: 0$ (Liu and McCreight, 2006).

Sixty-four L. serriola and L. virosa accessions in the Center for Genetic Resources, The Netherlands (CGN) collection were reported resistant to $\mathrm{Nr}: 1$ (Anonymous, 2008). Dominant resistance to $\mathrm{Nr}: 0$ and $\mathrm{Nr}: 1$ was claimed in L. serriola accession 10G.913571 (Thabuis et al., 2011).

The potential for the breakdown or failure of resistance conferred by the $\mathrm{Nr}$ gene was recognized shortly after release of $\mathrm{Nr}: 0$ resistant cultivars (Arend, 2003) and subsequently realized in Europe where the $\mathrm{Nr}$ gene was widely deployed (Thabuis et al., 2011). Although the gene has not been widely deployed in the United States as a result of different market requirements and numerous production niches (Davis et al., 1997), alternative sources of resistance to Nr:0 conditioned by other genes or mechanisms are desirable to prolong the effective life of $\mathrm{Nr}$ :0-resistant lettuce cultivars. Two potentially unique sources of resistance to $\mathrm{Nr}: 0$ were found in a survey of $\approx 1200$ cultivated and wild lettuce accessions (McCreight, 2008). Our objectives were to characterize and determine the inheritance of resistance to Nr:0 in Lactuca serriola accession PI 491093 and L. virosa accession PI 274378 .

\section{Materials and Methods}

This work was done using controlled infestations in greenhouses (13 experiments) and 
field cages (one experiment) and natural infestations in open fields (two experiments) in Salinas, CA. Eight of the experiments determined inheritance of resistance in PI 491093 (three) and PI 274378 (five); eight experiments evaluated the resistance phenotype of PI 491093.

Plant materials. The nine lettuce aphidsusceptible, resistant, or partially resistant accessions and cultivars used in these experiments were from various sources (Table 1). The seeds used in this research were produced in insect-free greenhouses at Salinas, CA. 'Salinas' served as the susceptible control (Ryder, 1979a). IVT 280 (Eenink and Dieleman, 1983), and 'Barcelona', which carries the $\mathrm{Nr}$ gene from IVT 280, served as resistant controls. Lettuce aphid-resistant 'Dynamite' (Arend et al., 1999) was included in one test for comparison with 'Barcelona'.

Crosses for genetic studies were made in a greenhouse using standard procedures for hand pollination of lettuce (Ryder, 1979b). PI 491093 was crossed with $L$. sativa cultivars Barcelona and Salinas. PI 274378 was crossed with four $L$. virosa accessions: completely resistant IVT 280, partially resistant CGN05332 (McCreight, unpublished data), susceptible PI 273597 (McCreight, unpublished data), and partially resistant PI 274375 (McCreight, unpublished data).

Lettuce aphid strain. Lettuce aphids were collected from a lettuce field at the USDAARS research station, Salinas, CA, in 2001 and reared on lettuce plants, usually 'Parris Island' and 'Salinas', in large, insect-proof, screened cages in a greenhouse. The colony was periodically supplemented with fieldcollected lettuce aphids through the duration of the testing to ensure representation of populations in commercial fields and on one occasion was completely re-established when infested by parasitoids. Resistance in IVT 280 and 'Barcelona' was always expressed against the lettuce aphids used in these studies; they may thus be regarded as Nr:0 (Thabuis et al., 2011).

Greenhouse tests. Seeds of each entry were sown in coarse, washed sand in $10 \mathrm{~cm} \times$ $10 \mathrm{~cm} \times 10-\mathrm{cm}$ plastic pots and covered with Tencate Miraf ${ }^{\circledR}$ geosynthetic fabric $(<\mathrm{http} / /$ www.tencate.com/ $>$ ) through germination in a greenhouse. Seedlings were transplanted at the one to two true leaf stage into $7.6 \mathrm{~cm} \times$ $7.6 \mathrm{~cm} \times 7.6-\mathrm{cm}$ plastic pots filled with a 1 potting mix: 1 sand mixture (by volume). Plants

Table 1. Plant materials used in experiments to determine the inheritance of lettuce aphid resistance in PI 491093 and PI 274378.

\begin{tabular}{|c|c|c|c|c|}
\hline $\begin{array}{l}\text { Accession } \\
\text { or cultivar }\end{array}$ & Lactuca sp. & $\begin{array}{l}\text { Lettuce aphid } \\
\text { resistance }\end{array}$ & Sources & Reference \\
\hline Barcelona & sativa & Resistant & Rijk Zwaan & \\
\hline CGN05332 & virosa & Partially resistant & Italy & (CGN, 2011) \\
\hline Dynamite & sativa & Resistant & Rijk Zwaan & (Arend et al., 1999) \\
\hline IVT 280 & virosa & Resistant & Rijk Zwaan & (Eenink and Dieleman, 1983) \\
\hline PI 273597 & virosa & Partially resistant & Germany & (USDA, 2011b) \\
\hline PI 274378 & virosa & Resistant & France & (McCreight, 2008; USDA, 2011c) \\
\hline PI 274375 & virosa & Susceptible & Poland & (USDA, 2011d) \\
\hline PI 491093 & serriola & Partially resistant & Turkey & (McCreight, 2008; USDA, 2011e) \\
\hline Salinas & sativa & Susceptible & USDA & (Ryder, 1979a) \\
\hline
\end{tabular}

were watered daily, fertilized weekly with $11915 \mathrm{~N}-2.2 \mathrm{P}-12.5 \mathrm{~K}-5 \mathrm{Ca}-2 \mathrm{Mg}$ (Peters Excel Cal-Mag; Scotts-Sierra Horticultural Products, Marysville, $\mathrm{OH}$ ) at a rate of $3.6 \mathrm{~g} \cdot \mathrm{L}^{-1}$ to deliver $540 \mathrm{mg} \cdot \mathrm{L}^{-1} \mathrm{~N}$, and grown under the natural photoperiod at 4 to $20^{\circ} \mathrm{C}$ (winter) and 10 to $40{ }^{\circ} \mathrm{C}$ (summer).

Plants were infested with $24 \mathrm{~h}$ or less or 24- to 48-h-old nymphs of lettuce aphid (five or 10 nymphs per plant). Infested plants were placed in insect-proof cages $(\approx 63 \mathrm{~cm} \times 63$ $\mathrm{cm} \times 63 \mathrm{~cm}$ ) with one entry per cage. Total numbers of aphids (nymphs + alates) were counted periodically from as early as $2 \mathrm{~d}$ through $111 \mathrm{~d}$ post-infestation (dpi).

Caged field test. Seedlings from seeds sown in the greenhouse as described previously were transplanted to standard lettuce beds in a field and included 'Salinas', 'Barcelona', PI 491093, and IVT 280. Plants were spaced $30 \mathrm{~cm}$ apart along the center of the bed and drip-irrigated as needed. Tests were arranged in randomized complete blocks with five replications. Plants were individually enclosed in aphid-proof cages $(\approx 46 \mathrm{~cm} \times 46 \mathrm{~cm} \times 46$ $\mathrm{cm})$ at the time of transplanting. One plant of each entry in each replication was infested with five aphids at the time of transplanting and at 2 and 4 weeks post-transplanting. Numbers of aphids were counted at 7-d intervals through 28 dpi. Other aphid species present were also counted.

Open-field tests. There were two naturally infested, open-field tests. The first test was started from seed, and entries were planted on standard lettuce beds, two entries per bed (one per seed line) and thinned to one plant per $30-\mathrm{cm}$; each experimental unit was $3.0 \mathrm{~m}$ long. The test included 'Salinas', 'Barcelona', PI 491093, IVT 280, seven families of $F_{2}$ Salinas $\times$ PI 491093 , and one family of $F_{2}$ Barcelona $\times$ PI 491093. The entries were arranged in a randomized complete block design with four replications. Natural infestation of the control cultivar Salinas by lettuce aphid was monitored weekly in both tests. When lettuce aphids were numerous on 'Salinas', three plants were randomly selected from each plot and taken to the laboratory where only lettuce aphids were counted.

The second open-field test was transplanted as described previously for the caged field test; included 'Salinas', 'Barcelona', PI 491093, and IVT 280; and was located in a commercial lettuce production area, $8.9 \mathrm{~km}$ away from the caged field test. The entries (Ryder, 1979a) were arranged in a randomized complete block design with three replications. Each replication included three plants of IVT 280 and five plants each of the other three entries. Natural infestation of the control cultivar Salinas by lettuce aphid was monitored weekly, and when aphids were numerous on 'Salinas' (40 dpi), the plants were taken to the laboratory where all aphids were counted. Lettuce aphid counts were totaled separately from other aphid species.

Data analysis. Statistical analyses and means comparisons were done using JMP 8.0.1 (SAS Institute, Cary, NC). Greenhouse data were analyzed as complete random designs. Caged and open-field data were analyzed as randomized complete block designs.

\section{Results and Discussion}

Inheritance of partial resistance in PI 491093. Mean numbers of lettuce aphids on 'Salinas' at 14 and 40 dpi were significantly $(P=0.05)$ higher than on PI 491093 and six $\mathrm{F}_{1}$ progenies from crosses of PI 491093 with 'Salinas' and 'Barcelona' (Table 2). Numbers of lettuce aphid on the three $F_{1}$ Salinas $\times$ PI 491093 progenies were not significantly higher than the numbers on three $F_{1}$ Barcelona $\times$ PI 491093 progenies (Table 2). These data suggest that resistance to lettuce aphid in PI 491093 is dominant to susceptibility. Although the $F_{1}$ data suggest that resistance in PI 491093 is comparable to that in IVT 280, $\mathrm{F}_{2}$ data reveal the difference in their gene expression. In the greenhouse experiment on the $F_{2}$ Salinas $\times$ PI 491093, mean numbers of lettuce aphids on 'Salinas' were many fold and significantly $(P=0.05)$ higher than on PI 491093 and their $F_{2}$ at 15 and 36 dpi (Table 2 ). There was a considerable overlap in aphid distributions on the parents and their $\mathrm{F}_{2}$ at 15 dpi (Fig. 1A), but by 36 dpi, lettuce aphids on the susceptible 'Salinas' increased significantly and resulted in higher densities per plant than on PI 491093 and their $F_{2}$ (Fig. 1B). The wide range in number of lettuce aphids per plant of PI 491093 indicates that the resistance is partial in contrast to the complete resistance in IVT 280 (Eenink and Dieleman, 1983). The $\mathrm{F}_{2}$ segregated 87 partially resistant:33 susceptible at 36 dpi when the break point for partial resistant vs. susceptible was set at $73\left(=\right.$ mean + SE of the $F_{2}$; Table 2) lettuce aphids per plant, an acceptable fit to the expected 3:1 ratio for a single dominant gene $\left(\chi^{2}=0.40, P=0.54\right)$.

In the naturally infested field test of the $\mathrm{F}_{2}$ Salinas $\times 491093$ and the $F_{2}$ Barcelona $\times$ 491093, 'Salinas' had significantly $(P=0.05)$ higher aphid density than PI 491093, 'Barcelona', and IVT 280 on 8 July and 20 July (Table 2). 'Salinas' differed significantly from three of the seven $F_{2}$ Salinas $\times$ PI 491093 progenies and the $\mathrm{F}_{2}$ Barcelona $\times$ PI 491093 (Table 2) on 8 July. Mean numbers of lettuce aphids increased on all entries except IVT 280 by 20 July, and 'Salinas' had significantly higher aphid density than all seven of the $\mathrm{F}_{2}$ Salinas $\times$ PI 491093 progenies. Mean number of aphids on $\mathrm{F}_{2}$ Barcelona $\times$ PI 491093 was 
Table 2. Mean \pm SE numbers of lettuce aphids per plant of 'Salinas', 'Barcelona', PI 491093, IVT 280, and their $F_{1}$ and $F_{2}$ offspring in two greenhouse tests at different days post-infestation and on two dates in a naturally infested, open field test, Salinas, CA.

\begin{tabular}{|c|c|c|c|c|c|c|c|c|c|}
\hline \multirow{2}{*}{ Entry or cross } & & & & \multicolumn{6}{|c|}{$\overline{F_{2}}$} \\
\hline & \multicolumn{3}{|c|}{$\mathrm{F}_{1}$} & \multicolumn{3}{|c|}{ Greenhouse } & \multicolumn{3}{|c|}{ Field } \\
\hline Salinas & 15 & $16.7 \pm 2.3 \mathrm{a}$ & $69.1 \pm 13.5 \mathrm{a}$ & 25 & $162.1 \pm 14.0 \mathrm{a}$ & $378.9 \pm 13.5 \mathrm{a}$ & 27 & $16.1 \pm 5.3 \mathrm{a}$ & $54.0 \pm 7.8 \mathrm{a}$ \\
\hline PI 491093 & 11 & $1.3 \pm 0.6 \mathrm{~b}$ & $0.2 \pm 0.2 \mathrm{~b}$ & 23 & $70.9 \pm 88.9 b$ & $85.2 \pm 20.7 b$ & 25 & $4.1 \pm 1.6 \mathrm{bcd}$ & $3.9 \pm 1.0 \mathrm{~cd}$ \\
\hline IVT 280 & & & & & & & 27 & $0.0 \mathrm{~cd}$ & $0.0 \mathrm{~d}$ \\
\hline \multirow[t]{5}{*}{ Salinas $\times$ PI 491093} & 10 & $0.5 \pm 0.3 \mathrm{~b}$ & $0.9 \pm 0.3 \mathrm{~b}$ & 120 & $84.1 \pm 5.2 b$ & $66.3 \pm 6.5 b$ & 30 & $10.9 \pm 2.5 \mathrm{ab}$ & $23.7 \pm 4.7 \mathrm{~b}$ \\
\hline & 10 & $1.9 \pm 1.0 \mathrm{~b}$ & $3.5 \pm 0.6 \mathrm{~b}$ & & & & 25 & $7.4 \pm 1.8 \mathrm{bc}$ & $16.7 \pm 3.7 \mathrm{~b}$ \\
\hline & & & & & & & 23 & $11.9 \pm 3.1 \mathrm{ab}$ & $17.0 \pm 3.9 \mathrm{~b}$ \\
\hline & & & & & & & 22 & $11.8 \pm 3.3 \mathrm{ab}$ & $23.1 \pm 5.0 \mathrm{~b}$ \\
\hline & & & & & & & 24 & $8.2 \pm 3.9 \mathrm{bc}$ & $14.8 \pm 5.0 \mathrm{bc}$ \\
\hline \multirow[t]{3}{*}{ Barcelona $\times$ PI 491093} & 4 & $1.0 \pm 0.6 \mathrm{~b}$ & $0.0 \pm 0.0 \mathrm{~b}$ & & & & 23 & $0.3 \pm 0.2 \mathrm{~cd}$ & $1.0 \pm 0.4 \mathrm{~d}$ \\
\hline & 10 & $0.0 \pm 0.0 \mathrm{~b}$ & $1.4 \pm 0.3 \mathrm{~b}$ & & & & & & \\
\hline & 7 & $0.4 \pm 0.3 b$ & $0.7 \pm 0.4 \mathrm{~b}$ & & & & & & \\
\hline
\end{tabular}

${ }^{\mathrm{z}}$ Means within columns followed by different letters are significantly different $(P=0.05)$.

dpi $=$ days post-infestation.

\section{A 15 dpi}

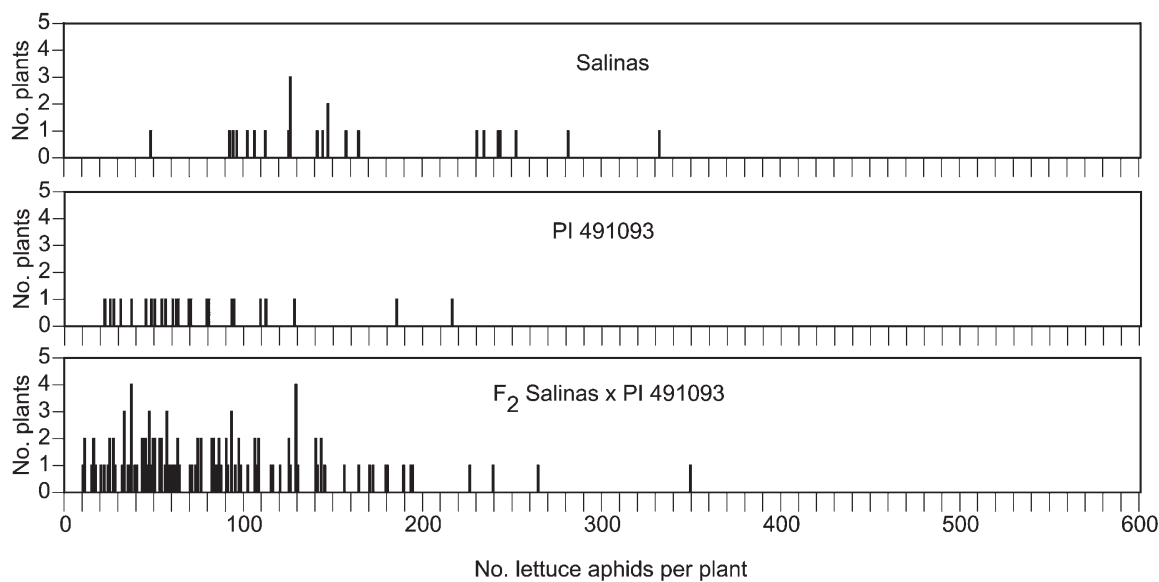

B 36 dpi

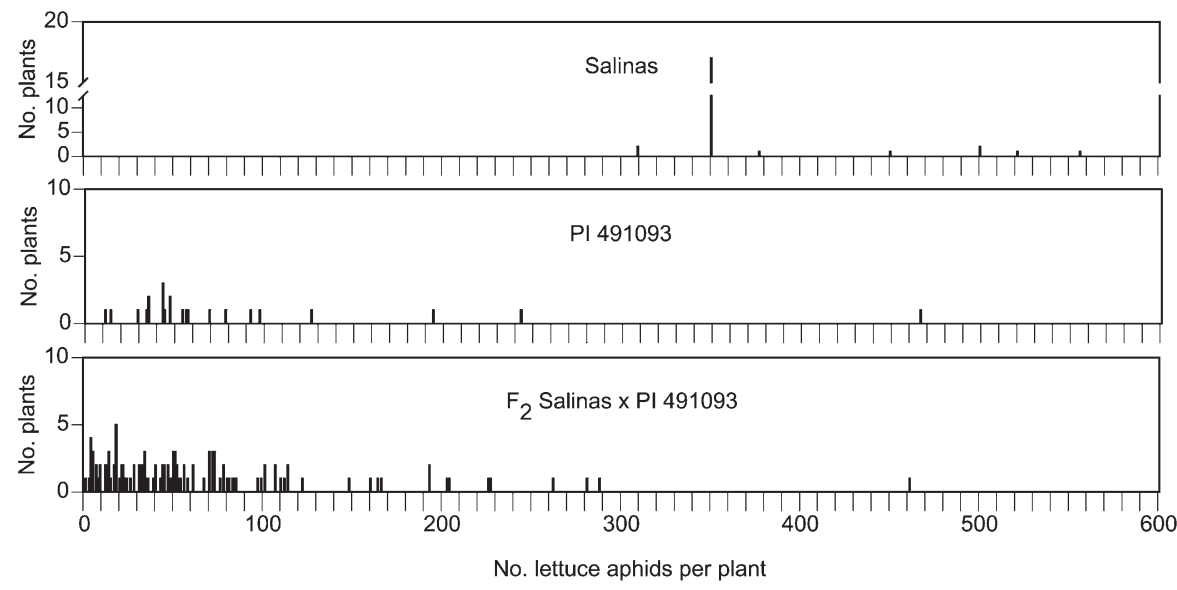

Fig. 1. Frequency distributions of numbers of lettuce aphids per plant of susceptible 'Salinas', partially resistant PI 491093 and $F_{2}$ Salinas $\times$ PI 491093 at 15 dpi (A) and 36 dpi (B); infested with five 24- to 48 h-old nymphs per plant in the greenhouse. $\mathrm{dpi}=$ days post-infestation.

1.0 ; this was significantly lower than on the $\mathrm{F}_{2}$ Salinas $\times$ PI 491093 progenies, which ranged from 14.8 to 23.7 .

Frequency distributions of lettuce aphid from the $\mathrm{F}_{2}$ field tests further revealed the difference in dominance and, possibly, the number of resistant alleles between the $L$. virosa-derived (IVT 280) resistance conditioned by the single dominant gene, $N r$, and the resistance in PI 491093 (Fig. 2). Numbers of lettuce aphids on susceptible 'Salinas' ranged from zero (one plant) to 100 (Fig. 2).
Distributions of IVT 280 (all zero lettuce aphids per plant) and 'Barcelona' (zero to two lettuce aphids per plant) were similar to each other. Numbers of lettuce aphids per plant of PI 491093 ranged from zero (16 plants) to 17 (one plant). The small sample of the $F_{2}$ Barcelona $\times$ PI 491093 segregated 20 completely resistant:three partially resistant where, based on the range of 'Barcelona', completely resistant ranged from zero to two lettuce aphids per plant and partially resistant had three or more lettuce aphids per plant, an acceptable fit to the expected $3: 1$ ratio for a single dominant gene $\left(\chi^{2}=1.17, P=0.28\right)$ with Yates correction (Yates, 1931). Mean number of lettuce aphids per plant for the seven $F_{2}$ Salinas $\times$ PI 491093 progenies was $19.7 \pm 1.8$; the combined data ranged from zero (36 plants) to 106 (one plant) lettuce aphids per plant (Fig. 2). The combined $F_{2}$ families in this naturally infested field test segregated 120 partially resistant:54 susceptible when the break point for partial resistant vs. susceptible was set at 22 (= mean + SE of the combined $\mathrm{F}_{2}$ ) lettuce aphids per plant, an acceptable fit to a three partially resistant:one susceptible $\left(\chi^{2}=3.38, P=0.07\right)$.

These results suggest that resistance to lettuce aphid strain Nr:0 is likely conferred by multiple alleles. IVT 280 is the source of $\mathrm{Nr}$, which confers complete resistance and is dominant to partial resistance in other L. virosa accessions as previously reported (Eenink and Dieleman, 1983). The $\mathrm{F}_{2}$ Barcelona $\times$ PI 491093 segregation had no susceptible segregants, which indicates that complete resistance in 'Barcelona' is allelic to partial resistance in PI 491093. Partial resistance in PI 491093 was dominant to susceptibility in 'Salinas'. We propose the revised gene symbols for resistance to lettuce aphid strain Nr:0: $N r: 0^{C}$ for complete resistance and $N r: 0^{P}$ for partial resistance, which was originally designated as $n r$ (Eenink and Dieleman, 1983) but may now be regarded as the symbol for susceptibility to all strains of lettuce aphid. The dominance relationships among these three alleles are $\mathrm{Nr}: \mathrm{O}^{C}$ (in IVT 280, 'Barcelona') $>$ $N r: O^{P}$ (in PI 491093) $>n r$ (in susceptible genotypes). 
Inheritance of resistance in PI 274378. Mean numbers of lettuce aphids on susceptible 'Salinas' and PI 273597 were significantly higher in three tests done in different seasons of the year than on resistant 'Barcelona', PI 2742378 , IVT 280, and reciprocal $\mathrm{F}_{1}$ proge-
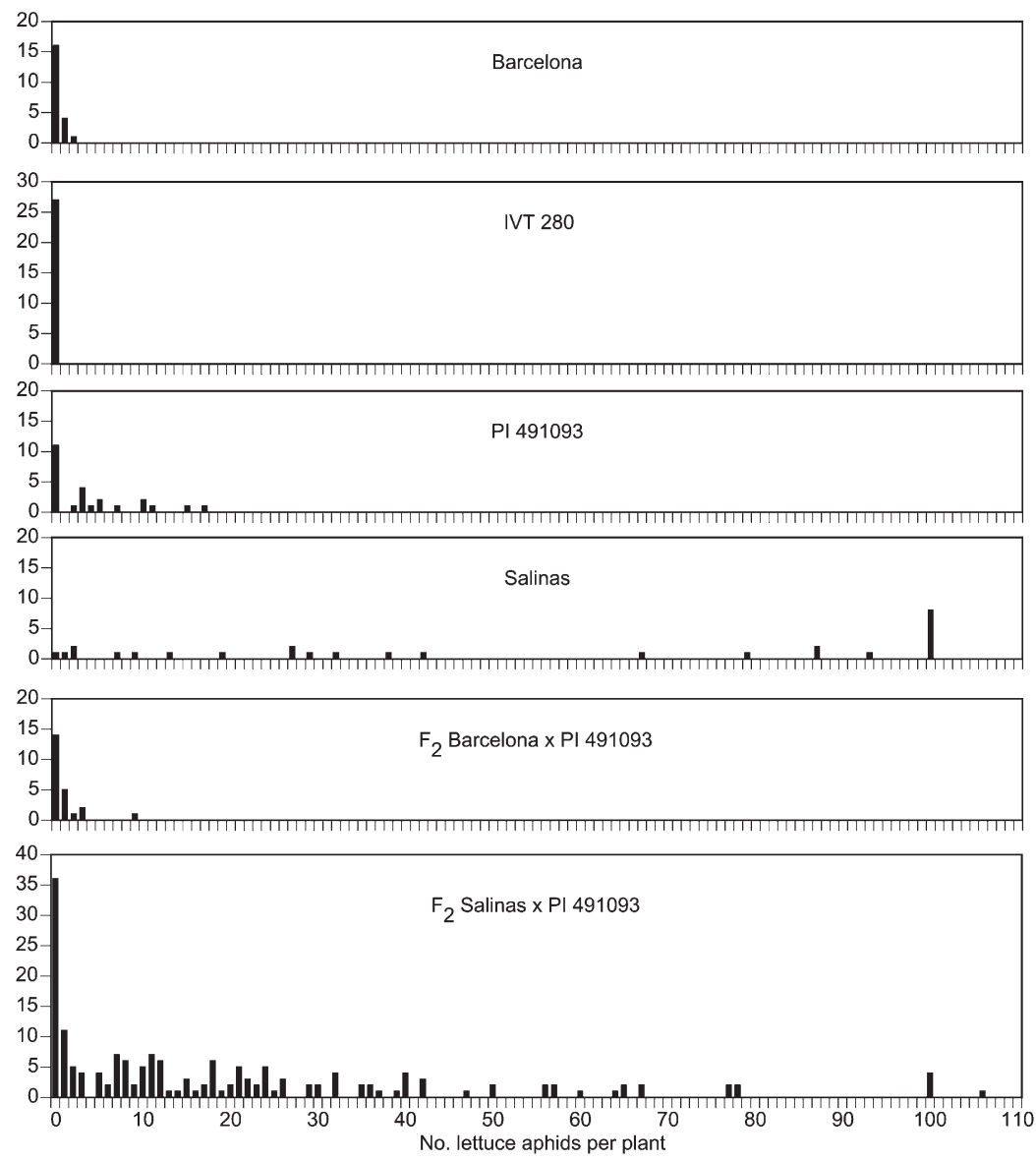

Fig. 2. Frequency distributions of numbers of lettuce aphids per plant in a naturally infested, open field; completely resistant 'Barcelona' and IVT 280, susceptible 'Salinas', partially resistant PI 491093, F2 Barcelona $\times$ PI 491093, and $F_{2}$ Salinas $\times$ PI 491093 (composite of seven families). dominant in the $\mathrm{F}_{1}$ PI $274378 \times$ CGN05332 (Spring test) and was comparable to IVT 280 and 'Barcelona'.

CGN05332 exhibited partial resistance in a separate greenhouse test with 'Salinas'; their respective mean number of lettuce aphids per plant 28 dpi were $6.8 \pm 1.6$ and $40.3 \pm 10.0$. The $\mathrm{F}_{2}$ PI $274378 \times$ CGN05332 did not segregate; mean numbers of aphids per plant 14 and 21 dpi were less than 1.0 (Table 3 ); at $28 \mathrm{dpi}$, no aphids were on 114 plants, one plant had a single aphid, and one plant had seven aphids. These data are comparable with the $\mathrm{F}_{2}$ Barcelona $\times$ PI 491093 data. Likewise, the $\mathrm{F}_{2}$ IVT $280 \times$ PI 274378 did not segregate and mean numbers of aphids per plant 14 and 21 dpi were also less than 1.0 (Table 3). These data demonstrate that complete resistance to lettuce aphid in PI 274378 is not the result of a unique new gene, but is allelic with the $N r: 0^{C}$ gene in IVT 280.

Nature of resistance in PI 491093. Partial resistance permits lettuce aphids to reproduce; the numbers of aphids per plant ranges over a wide range as these and previous (Eenink and Dieleman, 1983) data show. Numbers of live lettuce aphids were counted at different intervals starting 2 dpi for periods ranging up to 40 dpi in tests in which plants of PI 491093, 'Barcelona', 'Dynamite', IVT 280, and 'Salinas' were infested with 10 24-h-old nymphs (Fig. 3A-C). Numbers of live aphids declined on susceptible, partially resistant, and completely resistant genotypes by $2 \mathrm{dpi}$ in the three tests (Fig. 3A-C). The reduction was minimal or approximately one-third on susceptible and partially resistant genotypes; reduction was more severe on resistant genotypes, from approximately half to $100 \%$. After a short lag time, numbers of aphids on susceptible and partially resistant genotypes increased with a much greater increase on susceptible 'Salinas'. In one test, the numbers of aphids per plant on PI 491093 were virtually indistinguishable from completely resistant genotypes from 14

Table 3. Mean numbers \pm SE of lettuce aphids per plant at various days post-infestation in three greenhouse tests that included 'Salinas', 'Barcelona', PI 273597, PI 2742378 and IVT 280, and PI 274375, and $\mathrm{F}_{1}$ and $\mathrm{F}_{2}$ progenies from crosses among the L. virosa accessions; each plant infested with five 24- to 48-h-old nymphs; greenhouse; Salinas, CA.

\begin{tabular}{|c|c|c|c|c|c|c|c|c|c|c|}
\hline \multirow{2}{*}{ Entry } & \multicolumn{6}{|c|}{$\mathrm{F}_{1}$ generation } & \multicolumn{4}{|c|}{$\mathrm{F}_{2}$ generation } \\
\hline & \multicolumn{2}{|r|}{ Winter $^{2}$} & \multicolumn{2}{|r|}{ Spring $^{y}$} & \multicolumn{2}{|r|}{ Fall $^{\mathrm{x}}$} & \multicolumn{2}{|r|}{ Test $1^{\mathrm{w}}$} & \multicolumn{2}{|r|}{ Test $2^{\mathrm{v}}$} \\
\hline Salinas (S) & 10 & $119.1 \pm 9.9 \mathrm{a}$ & 15 & $186.4 \pm 21.2 \mathrm{a}$ & 15 & $53.7 \pm 9.0 \mathrm{a}$ & 20 & $237.8 \pm 24.0 \mathrm{a}$ & 20 & $344.0 \pm 39.8 a$ \\
\hline PI 273597 (S) & 10 & $104.7 \pm 16.0 \mathrm{a}$ & & & & & & & & \\
\hline PI 2742378 (CR) & & & 14 & $0.0 \mathrm{~b}$ & & & & & & \\
\hline IVT 280 (CR) & 15 & $6.5 \pm 1.5 \mathrm{~b}$ & 23 & $0.0 \mathrm{~b}$ & 24 & $0.0 \mathrm{~b}$ & & & 20 & $0.0 \mathrm{~b}$ \\
\hline PI 274375 (PR) & 9 & $16.6 \pm 3.1 \mathrm{~b}$ & & & & & & & & \\
\hline $\mathrm{F}_{1}$ PI $274378 \times$ IVT 280 & 8 & $3.6 \pm 1.0 \mathrm{~b}$ & & & 5 & $0.0 \mathrm{~b}$ & & & & \\
\hline $\mathrm{F}_{1}$ IVT $280 \times$ PI 274378 & & & 3 & $0.0 \mathrm{~b}$ & 12 & $0.0 \mathrm{~b}$ & & & & \\
\hline $\mathrm{F}_{1}$ PI $274378 \times$ CGN05332 & & & 4 & $0.0 \mathrm{~b}$ & & & & & & \\
\hline $\mathrm{F}_{2}$ PI $274378 \times$ CGN05332 & & & & & & & 77 & $0.1 \pm 0.1 \mathrm{c}$ & & \\
\hline $\mathrm{F}_{2}$ IVT $280 \times$ PI 274378 & & & & & & & & & 122 & $0.1 \pm 0.1 \mathrm{~b}$ \\
\hline
\end{tabular}

zPlanted 2 Feb. 2009, infested 4 Mar. 2009.

'Planted 4 Apr. 2006, infested 10 May 2006.

xPlanted 20 Oct. 2006, infested 17 Nov. 2006.

wPlanted 26 June 2009; infested 10 July 2009.

vPlanted 24 July 2009; infested 6 Aug. 2009.

$\mathrm{dpi}=$ days post-infestation. 

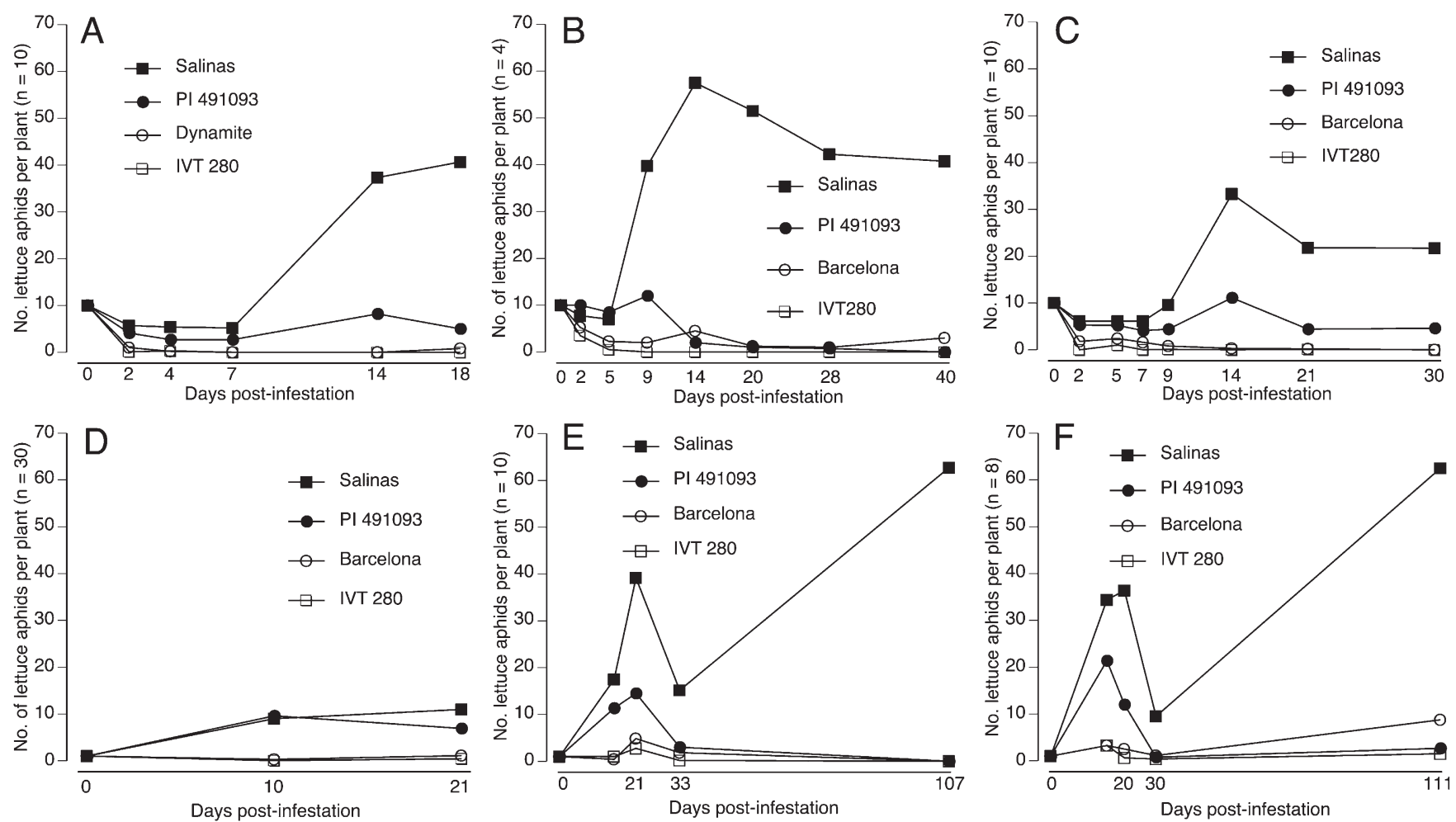

Fig. 3. Mean numbers of lettuce aphids per plant on resistant and susceptible lettuce at various days post-infestation. Plants infested with 1024 -h-old nymphs per plant (A-C) or a single 24-h-old nymph per plant $(\mathbf{D}-\mathbf{F})$ in the greenhouse.

Table 4. Mean numbers \pm SE of lettuce aphid and other unidentified aphid spp. on lettuce aphid-susceptible 'Salinas', partially resistant PI 491093 , and completely resistant 'Barcelona', and IVT 280 at $28 \mathrm{~d}$ post-infestation after three infestation dates of plants in field cages $($ No. $=5)$ and in a naturally infested open field; $2008 .^{z}$

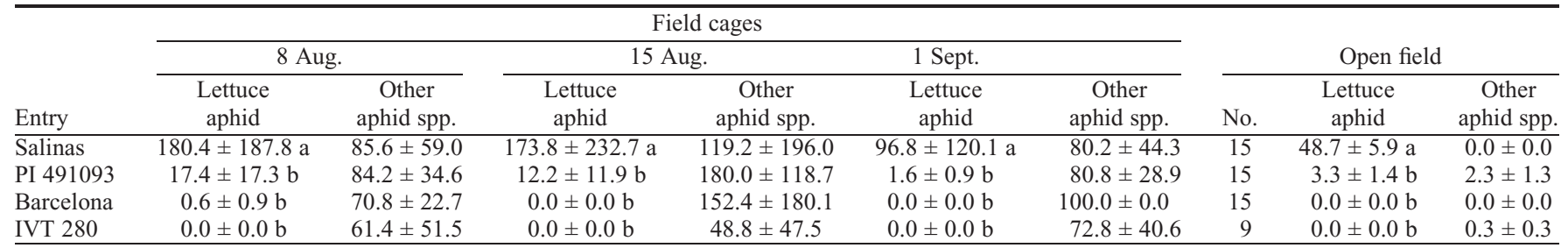

${ }^{\mathrm{z}}$ Lettuce aphid means followed by different letters are significantly different, $P=0.05$. Numbers of other aphid spp. did not differ significantly among the entries in any test.

through 40 dpi (Fig. 3B). In another test, mean numbers of aphids remained approximately five per plant except for a period $\approx 14 \mathrm{dpi}$ (Fig. 3C).

In three similar tests, plants were infested with a single 24 -h nymph. The initial count was made 10 to $20 \mathrm{dpi}$ and the final count was made from 21 to 111 dpi (Fig. 3D-F). In one test (Fig. 3D) there was no significant difference between 'Salinas' and PI 491093 for number of aphids at $10 \mathrm{dpi}$, but by $21 \mathrm{dpi}$, PI 491093 had significantly fewer aphids than 'Salinas', although the mean number of aphids per plant on either was very low. Numbers of lettuce aphids on 'Salinas' and PI 491093 followed similar patterns through $\approx 30$ dpi (Fig. $3 \mathrm{E}-\mathrm{F}$ ), although the numbers on PI 491093 were significantly lower than on 'Salinas' but not significantly greater than on IVT 280 or 'Barcelona' through the end of the tests.

Numbers of lettuce aphids per plant were significantly higher on 'Salinas' than 'Barcelona', IVT 280, and PI 491093 in a caged field test (Table 4). 'Barcelona' and IVT 280 were essentially aphid-free, whereas mean numbers of aphids on PI 491093 ranged from 17.4 when infested immediately after transplanting to 1.6 when infested 4 weeks post-transplanting. Partial resistance provided a marked and significant level of protection against lettuce aphid infestation in this test. The cages were not completely insect-proof as indicated by high numbers of other aphid species on the plants regardless of their aphid resistance genotype (Table 4). These data confirm the specificity resistance in lettuce aphid as previously reported (Reinink et al., 1995). Other crops have been noted as hosts of different aphid species, whereas their resistance to aphids is speciesor biotypes-specific (Dogimont et al., 2010). A given lettuce genotype may possess resistance to more than one aphid (Reinink and Dieleman, 1989).

Partial resistance in PI 491093 provided protection against natural infestation by lettuce aphid in a replicated, naturally infested field test. 'Salinas' had significantly greater numbers of lettuce aphids than PI 491093, 'Barcelona', and IVT 280 (Table 4). Other aphid species were present at very low levels.

Partial resistance to lettuce aphid in $L$. serriola accession PI 491093 is dominant to susceptibility in L. sativa cultivars, e.g., 'Salinas'. Partial resistance is controlled by a single dominant gene that appears to be identical to the gene in L. virosa accession IVT 273 and allelic to the gene for complete resistance in $L$. virosa accession IVT 280, the source of resistance for all currently available lettuce aphid-resistant lettuce cultivars. Transfer of complete resistance from IVT 280 was a lengthy, complicated process that involved interspecific crosses to introgress a unique gene from a tertiary gene pool into cultivated lettuce (Arend et al., 1999; Eenink et al., 1982a; Lebeda et al., 2007).

Partial resistance to lettuce aphid provides a level of protection that is of potential value to lettuce production. Greenhouse data suggest 
increased expression or effectiveness of partial resistance with plant growth. Partial resistance may, either alone or as a component of integrated pest management, delay or prevent emergence of resistance-breaking strains where complete resistance has not been widely deployed. Lactuca serriola is in the primary gene pool for cultivated lettuce; transfer of partial resistance from PI 491093 is, therefore, expected to be easier than transfer from the tertiary gene pool.

\section{Literature Cited}

Anonymous. 2004. Australian Vegetable and Potato Growers Federation. Lettuce aphid outbreak update. $<$ http://www.ausveg.com.au/assets/contentitems/ public/1268/LettuceAphidFAQsConsumers.pdf $\$$.

Anonymous. 2008. Resistance to the lettuce leaf aphid Nasonovia ribisnigri. Disclosure Number IPCOM000176078D dated 4 Nov. 2008. IP.com Prior Art Database Disclosure. <http:// ip.com/IPCOM/000176078>.

Arend, A.J.M.d. 2003. The possibility of Nasonovia ribisnigri resistance breaking biotype development due to plant host resistance: A literature study, p. 75-81. In: Hintum, T.J.L.v., A. Lebeda, D.A. Pink, and J.W. Schut (eds.). EUCARPIA leafy vegetables 2003. Proc. of the EUCARPIA Meeting on Leafy Vegetables Genetics and Breeding, Noordwijkerhout, The Netherlands, 19-21 Mar. 2003. Centre for Genetic Resources, Wageningen, The Netherlands.

Arend, A.J.M.d., A. Ester, and J.T.v. Schijndel. 1999. Developing an aphid-resistant butterhead lettuce "Dynamite". Eucarpia Leafy vegetables '99. Palacky University, Olomouc, Czech Republic. p. 149-157.

Barber, M.D., G.D. Moores, G.M. Tatchell, W.E. Vice, and I. Denholm. 1999. Insecticide resistance in the currant-lettuce aphid, Nasonovia ribisnigri (Homoptera: Aphididae) in the UK. Bul. Ent. Res. 89:17-23.

Blua, M.J. 1997. Vectors, p. 51-54. In: Davis, R.M., K.V. Subbarao, R.N. Raid, and E.A. Kurtz (eds.). Compendium of lettuce diseases. APS Press, St. Paul, MN.

CGN. 2011. The Centre for Genetic Resources, The Netherlands. <http://www.cgn.wur.nl/UK/CGN+ Plant+Genetic+Resources/Search + and + ...mplasm/ On+line + search $/$ Default.htm?page $=$ detail $\&$ acnumber $=$ CGN05332 $>$.

Chaney, B. 1999. Lettuce aphid update. Monterey County Crop Notes. University of California Cooperative Extension, Salinas, CA. April: 1, 7.

Davis, R.M., K.V. Subbarao, R.N. Raid, and E.A. Kurtz. 1997. Compendium of lettuce diseases. APS Press, St. Paul, MN.

Dogimont, C., A. Bendahmane, V. Chovelon, and N. Boissot. 2010. Host plant resistance to aphids in cultivated crops: Genetic and molecular bases, and interactions with aphid populations. Comptes Rendus Biologies 333:566-573.

Eenink, A.H. and L.F. Dieleman. 1983. Inheritance of resistance to the leaf aphid Nasonovia ribis-nigri in the wild lettuce species Lactuca virosa. Euphytica 32:691-695.

Eenink, A.H., R. Groenwold, and F.L. Dieleman. 1982a. Resistance of lettuce (Lactuca) to the leaf aphid Nasonovia ribisnigri. 1. Transfer of resistance from $L$. virosa to $L$. sativa by interspecific crosses and selection of resistant breeding lines. Euphytica 31:291-300.

Eenink, A.H., F.L. Dieleman, and R. Groenwold. 1982b. Resistance of lettuce (Lactuca) to the leaf aphid Nasonovia ribis nigri. 2. Inheritance of the resistance. Euphytica 31:301-304.

Forbes, A.R. and J.R. MacKenzie. 1982. The lettuce aphid, Nasonovia ribisnigri (Homoptera: Aphididae) damaging lettuce crops in British Columbia. J. Ent. Soc. British Columbia 79: 28-31.

Lauritzen, E. 2011. Monterey County Crop report 2010. Office of the Agricultural Commissioner, Monterey County, CA. <http://ag.co.monterey. ca.us/>.

Lebeda, A., E.J. Ryder, R. Grube, I. Dolezalova, and E. Kriskova. 2007. Lettuce (Asteraceae; Lactuca spp.), p. 377-472. In: Singh, R.J. (ed.). Genetic resources, chromosome engineering, and crop improvement. CRC Press, New York, NY.

Liu, Y.-B. 2004. Distribution and population development of Nasonovia ribisnigri (Homoptera: Aphididae) in iceberg lettuce. J. Econ. Entomol. 97:883-890.

Liu, Y.-B. 2005. Ultralow oxygen treatment for postharvest control of Nasonovia ribisnigri (Homoptera: Aphididae) on iceberg lettuce. J. Econ. Entomol. 98:1899-1904.

Liu, Y.-B. and J.D. McCreight. 2006. Responses of Nasonovia ribisnigri (Homoptera: Aphididae) to susceptible and resistant lettuce. J. Econ. Entomol. 99:972-978.

McCreight, J.D. 2008. Potential sources of genetic resistance in lettuce to the lettuce aphid, $\mathrm{Nasa}$ novia ribisnigri (Mosely) (Homoptera: Aphididae). HortScience 43:1355-1358.

Mou, B. 2009. Nutrient content of lettuce and its improvement. Current Nutr. Food Sci. 5:242248.

Painter, R.H. 1980. Breeding plants resistant to insects. John Wiley \& Sons, New York, NY.

Palumbo, A.D. 2000. Seasonal abundance and control of the lettuce aphid, Nasonovia ribisnigri, on head lettuce in Arizona. <http://ag. arizona.edu/pubs/crops/az1177-1171m.pdf $>$. In: Byrne, D.N. and P. Baciewicz (eds.). 2000 vegetable report. University of Arizona College of Agriculture 2000 and Life Sciences. <http:// ag.arizona.edu/pubs/crops/az1177/>.

Reinink, K. and F.L. Dieleman. 1989. Resistance in lettuce to the leaf aphids Macrosiphum euphorbiae and Uroleucon sonchi. Ann. Appl. Biol. 115:489-498.

Reinink, K., F.L. Dieleman, and R. Groenwold. 1995. Inheritance of partial resistance to the leaf aphids Macrosiphum euphorbiae and Uroleucon sonchi in lettuce. Ann. Appl. Biol. 127:413-424.
Ryder, E.J. 1979a. 'Salinas' lettuce. HortScience 14:283-284.

Ryder, E.J. 1979b. Leafy salad vegetables. AVI Publ. Co., Westport, CT.

Ryder, E.J. 2002. The new salad crop revolution, p. 408-412. In: Janick, J. and A. Whipkey (eds.). Trends in new crops and new uses. ASHS Press, Alexandria, VA.

Stufkens, M.A.W., S.E. Nichol, S.R. Bulman, and G.M. Drayton. 2004. Incursion of the lettuce aphid into Tasmania - Could it have blown over from New Zealand? New Zealand Plant Protection 57:340 (abstr.).

Stufkens, M.A.W. and D.A.J. Teulon. 2003. Distribution, host range and flight pattern of the lettuce aphid in New Zealand. New Zealand Plant Protection 56:27-32.

Stufkens, M.A.W., D.A.J. Teulon, and S.R. Bulman. 2002. Nasonovia ribisnigri, a new aphid pest found on lettuces (Lactuca sativa L.) and Ribes spp. in Canterbury. New Zealand Plant Protection 55:437 (abstr.).

Stufkens, M.A.W. and A.R. Wallace. 2004. Effectiveness and persistence of six insecticides for control of lettuce aphid on field lettuce in Canterbury, New Zealand. New Zealand Plant Protection, Volume 57, 2004. Proc. of a conference, Hamilton, New Zealand, 10-12 Aug. 2004. p. 233-238.

Thabuis, A.P.P., K.C. Teekens, and Z.O. Van Herwijnen. 2011. Lettuce that is resistant to the lettuce aphid Nasonovia ribisnigri biotype 1. World Intellectual Property Organization. PCT/EP2010/067588.

USDA. 2011a. Economic Research Service U.S. Lettuce Statistics. <http://usda.mannlib. cornell.edu/MannUsda/viewDocumentInfo.do? documentID $=1576>$.

USDA. 2011b. ARS, National Genetic Resources Program. Germplasm Resources Information Network-(GRIN) [online database]. National Germplasm Resources Laboratory, Beltsville, MD. $<$ http://www.ars-grin.gov/cgi-bin/npgs/swish/ accboth? query=PI+273597>.

USDA. 2011c. ARS, National Genetic Resources Program. Germplasm Resources Information Network-(GRIN) [online database]. National Germplasm Resources Laboratory, Beltsville, MD. <http://www.ars-grin.gov/cgi-bin/npgs/acc/ display.pl?1205938>.

USDA. 2011d. ARS, National Genetic Resources Program. Germplasm Resources Information Network-(GRIN) [online database]. National Germplasm Resources Laboratory, Beltsville, MD. <http://www.ars-grin.gov/cgi-bin/nggs/acc/ display.pl?1205936>.

USDA. 2011e. ARS, National Genetic Resources Program. Germplasm Resources Information Network-(GRIN) [online database]. National Germplasm Resources Laboratory, Beltsville, MD. <http://www.ars-grin.gov/cgi-bin/nggs/acc/ display.pl?1386029>.

Yates, F. 1931. Contingency tables involving small numbers and the $\chi^{2}$ test. Suppl. J. Royal Stat. Soc. 1:215-235. 